\title{
ORGANIZATION OF FOLK ATHLETIC GAMES IN THRACE
}

\author{
Evangelos Albanidis, Dimitrios Goulimaris, Vasileios Serbezis
}

\begin{abstract}
The aim of this paper is to study folk games which were organized by the Greek at cultural events in Thrace taking as its source the literature that has been published on the topic and fieldwork materials. Research has revealed that Thracians celebrated almost every festival and celebration with wrestling matches or a horse racing event. These spontaneous athletic games were connected with religion while these were often performed at religious festivals. The winners were mostly awarded lambs and goats, which were the offerings of believers to the church or offerings of shepherds for having had a good year and for their flocks. At special weddings, the Greek also organized horse races and wrestling matches.
\end{abstract}

Key words: folk games, footraces, Greece, horse races, Thrace, wrestling matches

\section{INTRODUCTION}

Thrace is spread over three present-day countries: Greece, Turkey, and Bulgaria. The area has had no clearly defined boundaries ever since the ancient times. In the present study, Thrace is being studied in its greater national and geographical boundaries, those being the Struma (Strymōn) River to the west, the Danube to the north, the Thracian Sea to the south, and the Black Sea and Propontis (the Sea of Marmara) to the east (Oberhumer 1936: 394-396, Samsaris 1980: 13-17). Christian Thracians, who lived in North and East Thrace (presentday Bulgaria and Turkey, respectively) until 1923, had to abandon their homeland and settle mainly in West Thrace (present-day Greece) (Svolopoulos 2000: 265-266).

At the beginning of the 20th century, horse races, wrestling matches, footraces, jumping or stone-throwing events took place in many Greek areas in the course of cultural events, like religious celebrations, weddings, etc. These folk games were held in the Byzantine Era (330-1453 AD) as well as during the Turkish occupation in the area (1453-1821 AD). Apart from literary sources, references to these sports events can be found in great numbers in folk songs (Nimas 2002: 135-188; Tsiantas 1980: 33-47). The article overviews the occur- 
rence of these sports events in Thrace. The aim of this paper is to study 20thcentury folk games which were organized by the Greek Christians as part of Thracian cultural events, taking as its source relevant literature and fieldwork materials. The study duly explores events in which Greek Christians and Muslims, who coexist in western Thrace even today, participated together, and those in which Greek Christians and Bulgarians, who used to coexist in Northern Thrace until 1923, have taken part.

\section{HORSE RACES}

The analysis of and elaboration on the sources mentioned above reveal that in Thrace horse races were held in the first half of 20 th century but were suppressed after the introduction of agricultural technology and technological advances in daily life. Until the 1960s, for the Christian Thracians in Greece the horse was not only a means of transport which helped them in their everyday tasks but had an important role in their lives and symbolized wealth in the society. Not everybody owned a horse: it was the privilege of the rich and the devoted who could afford to own and breed them.

Spontaneous horse races were held in different circumstances: for example, when a limited group of people took horses to graze. Organized horse races were held at specific events, like the Anchialos games (the tradition is now continued in Bulgaria), where they had a special meaning and added exquisite glamour to the event. As Theodoros Mavromatis claims in an article published in 1939, horse races were held during carnivals:

On the last day of carnival, before sunset, the quarter of Souda and Jesus was very crowded. All the people in Anchialos were awake. Men, women, and children were gathering there. They were sitting on low piles, waiting anxiously and with great excitement the arrival of horses which were racing from Pigadia to the finish in Desi, and they wanted to see whose horse came first and who the winner was. On that day the men of Anchialos who owned good horses (Giannis Tsoumeris, Hatzithoroglou Blasakis) sent their horses to participate in the racing and either the owners of the horses were riding them or the horses were given to young skilful horse riders like Triantafyllos Stamatiou. A committee gave the command to start the race. The price for the winner was a sack of barley or oats... The horse race was about 1.5-2 kilometers long and took place on a sandy beach. (Mavromatis 1939: 6163) 
Until the 1930s, analogous horse races were organized by the citizens of Didymoteicho on the feast day of St Blaise (Agios Vlasios) on February 11. The origins of this festival have been lost throughout the years. According to a legend, the Turks conquered Didymoteicho in Evros prefecture in Greece after tricking the princess into opening the heavy gates of the castle while the king was away. After the Turkish invasion, the princess, in despair, climbed up to a high tower and fell over the precipice. The king was feasting in the countryside with his army, and when he was informed about what had happened, he was so confident about the strength of the fortification walls of the castle that he said, "if this cock comes out of the kettle and crows, [...] then I will believe that the town has been conquered" (Manakas 1963: 50-51).

Indeed, the cock came out the kettle and crowed and the king believed what had happened. On this specific spot there is a country church dedicated to St Blaise, who is honored as informer of the conquest of the Turks. An analogous incident is known about Naupactus, a city in southern Greece. Until the present day, this area has been called Taouk gemez ('uneaten chicken') in Turkish. Under this name a horse race was held there until the Second World War: the race started in Taouk gemez, and ended at the gate Tabakia through which, it is believed, the Turks invaded the castle. The horse riders who competed in the race were called Ai-Vlasites ('ancestors of St Blaise') and the race was obviously a reenactment of the king's and his army's anxious efforts to arrive at Didymoteicho on horses to save what was left of the castle.

In the area of North Evros in West Thrace, horse races were often held during festivals. Sources mention that horse races usually took place in Inoi of Orestiada on May 2 (the feast day of St Athanasius), in Marasia on August 6 (the Transfiguration of Jesus), in Kastanies on the feast day of St George, and in Orestiada on the feast day of St Theodore. It seems that they were not organized every year but only after a specific proclamation. Villagers who decided to include a horse race as part of a festival announced it in the entire area. A church committee was responsible for announcing the event and designating the venue and

Figure 1. Map of Thrace.

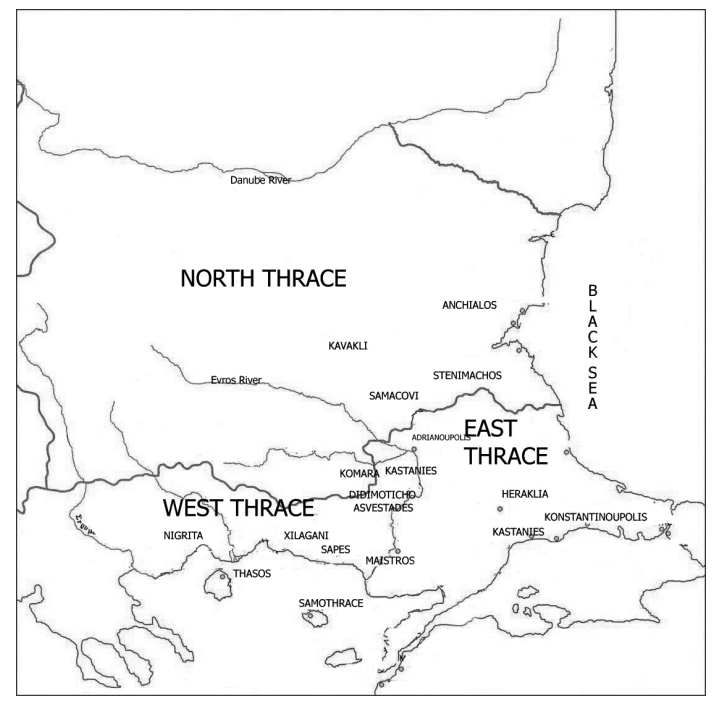


the starting point of the race. The committee also chose in advance the prize that would be awarded to the winner: this was usually a ram, a lamb or a calf. The prizes were donated by the church committee or a local wealthy person. The length of the distance that racers had to cover was usually 3,4 or 5 kilometers. The starting signal was given by a person appointed by the church committee of the village which organized the festival. There was no previously determined order at the start and on race track. Each rider could choose the position that he wanted. The horse races always took place before noon; the Holy Mass had to be over by the time the riders arrived at the village. The winner, the first person to cross the finish line, was taken to the church committee to be awarded his prize. If there was any doubt about the winner the matter would be solved on the spot. Anybody could participate in the horse races regardless of his age or the age of the horse and whether his horse had a saddle or not (Basogianni 1993: 7-10).

Next to the horse races described above, a series of horse races which were held in the village of Komara of North Evros on July 7, the feast day of St Kyriaki, suddenly became very famous. These games were performed until the end of the 1960s and discontinued with advances in agricultural technology, when horses were replaced by tractors. Because of the lush vegetation and large grasslands by the river, horses were bred in large numbers in this village. Fieldwork informants have confirmed that horse races held on the name day of St Kyriaki were a remnant of horse races of much larger scale. From Kirk Bournar ('Forty Springs') of Kyprinos to Adrianople (present-day Edirne in Turkey) Greek and Turks held horse races between until the end of the 19th century. The winner of these events was awarded a large sum of money.

Many young men from the village of Komara participated in the races held on the feast day of St Kyriaki. The racers wearing white shirts covered eight kilometers on horses without saddles. The prize for the winner was a lamb or a ram, provided by the church committee, and the winning horse was decorated with neckerchiefs. Neckerchiefs were also given as a prize to the holders of the second and third place. All the horses were presented to the spectators to the accompaniment of a tabor playing, and the rhythm became much faster as the horses arrived at the finish line.

Similar horse races were also organized before 1939 in Sapes in West Thrace as a part of a great trade fair and cattle festival, held at the beginning of September. Horse races took place on Saturday, the last day of the ten-day festival. Both Christian and Muslim horse riders participated in the games. Three different kinds of horse races were held: the first race started in the Arsakio village, the second one at the train station of Mesti, and the third one in the 


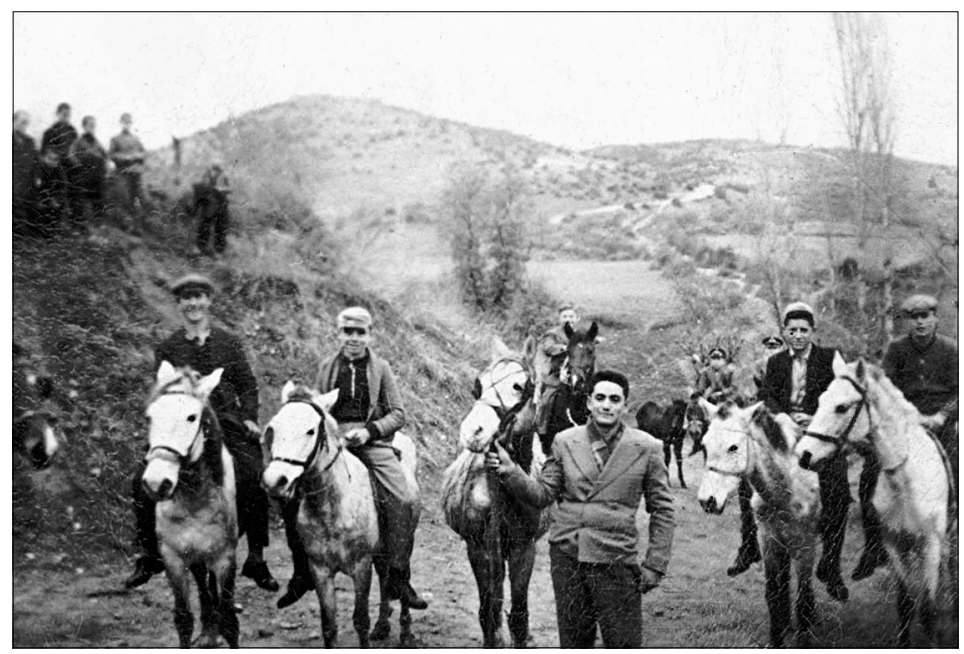

Figure 2. Horse race in Komara.

Aratos village (10 km from Sapes). All the horse races ended on the threshing squares of Sapes, the place where the trade fair was held.

\section{Wedding horse races}

Fieldwork materials have revealed that in Evros prefecture and in other regions of Greece, horse races were also held at weddings (Nimas 1997: 375-397; Nimas 2000: 221-240). Young unmarried men from the groom's village, at the ages of 30-50, took part in wedding horse races. According to the tradition, the men competed in who would be the first one to arrive at the groom's house to announce the bride's arrival. After that the wedding ceremony could start. The groom offered the winner of the horse race two white neckerchiefs, one for the racer and one for his horse, or a pillow. Similar wedding horse races were also known to be held in the Mikri Doxipara village and in the Komara village.

\section{WRESTLING MATCHES}

Wrestling was one of the most popular activities of the ancient Greeks. Wrestling excited the Byzantines, and the enslaved people, and continues to be popular among the Greek Christians in Thrace even today. Wrestling matches were held at all major festivals, every bigger traditional event, even at weddings. Wrestling matches were held in Thrace during the Ottoman rule and 
when the area was a part of Bulgaria with the consent of the Turkish or the Bulgarian authorities because it had preserved its character of an unarmed and peaceful activity. Everybody, regardless of nationality and without particular formalities, was allowed to participate in these wrestling matches (Varvounis 2001: 195-216).

Organization. At the beginning of the 20th century, organizing the wrestling matches was the responsibility of the church committee and the local notables of the village where the festival was held. If the wrestling match was held at the wedding, then the match was organized by the groom and the bratimous, close friends of the groom. The church committee and the notables - local police officers, the village teacher or a teacher from the surrounding area, and an experienced wrestler - served as judges during the match. The judges arranged the wrestlers in couples according to their age or experience, with no major formalities. Children, teenagers, and adults could participate in the wrestling games by just naming the category in which they wanted to participate, depending on their physical and psychological endurance. Usually there were two categories of wrestlers. Prota ('the first') was the category for experienced wrestlers and deftera ('the second') was the second category for younger and less experienced wrestlers. The categorization was based on experience rather than age. At major festivals, however, wrestlers competed in four categories. For example, at the festival held on Thomas Sunday in Nigrita, a city in the Serres prefecture, Greece, wrestlers competed in three categories. In the old days, the category prota was called the bas, deftera ('the second') was called bouiouk orta, and the category trita ('the third') was called kioujouk orta and teleftea ('the last one') or basma ('low-quality cloth')(Varvounis \& Dimaki 2000: 89).

Rules of the game and announcing the winner. At the competition, a draw was impossible. The winner was the wrestler who managed to turn around and hold his opponent in a way that his two shoulder blades were pinned to the ground, "his back eating dust". Victory was also attained by grabbing the opponent and turning him over his shoulders. While there were no written rules to the games, everybody knew that kicks and dangerous grasping of the head and genitals were strictly forbidden. These rules of wrestling applied everywhere in Thrace.

Game performance. At first, the games opened with the fights of young wrestlers and the most experienced men followed. For the fight, wrestlers took off almost all their clothing and they wore only a short knee-length periskelida which was made of veal or goat skin and was called ki(ou)spet in Turkish. 
Figure 3. Winner holding his trophy at a horse race in Komara in 1952.

Periskelida were tight knee-length trousers tightly tied around the knee with rope or leather strings. Before and during the fight, wrestlers smeared their bodies and periskelida with oil in order to make gripping more difficult for the opponent, and a good grasp of the technique became the main element of winning.

During the matches, the wrestling was accompanied by bagpipe (gaida) music. Very often the matches took place to the accompaniment of two clarinets and a tabor. The music played on the arena fol-

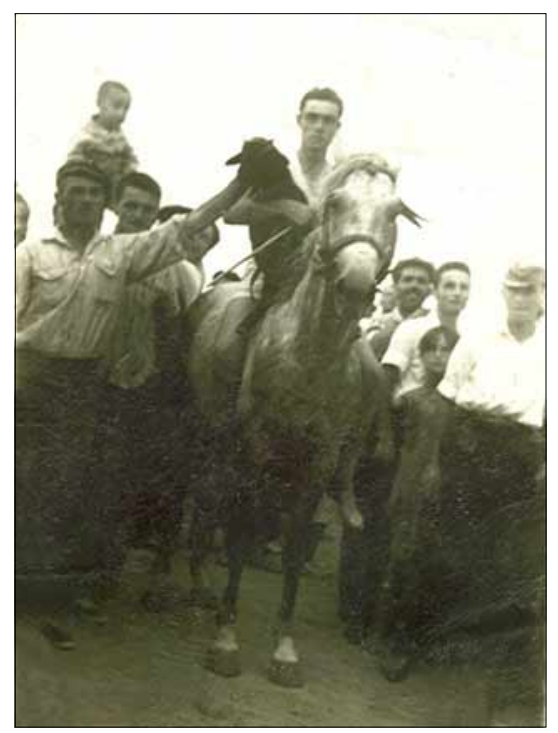
lowed highly varied rhythm; the types of music played consisted of three melodious and rhythmic parts. The first part, played at a slow rhythm, was performed at the beginning of the match, the second part was played in a faster tempo, and the third part, which had the fastest free rhythm, was performed when the wrestling match was almost over and the winner was clearly determined (Ekaterinidis 2000: 322; Tolides 1987: 212).

Before the beginning of the wrestling match, the participants performed a special ritual which helped, on the one hand, the wrestlers to warm up and, on the other hand, made it easier for the wrestlers to estimate their potential.

Prizes and announcing the winner. Winners were given as a prize various practical items, such as neckerchiefs, flutes, mirrors, and at major festivals a lamb or a ram. Less valuable prizes were given to winners of minor categories, whereas the main prize, a ram, was awarded to a male winner. The winner was greeted by a cheering crowd. At the end of the match, the opponent held the winner from his waist and lifted him up twice (Basogianni 1933: 7-10; Ktenidis \& Kotinis 1969: 136-137).

\section{WRESTLING MATCHES AT VARIOUS THRACIAN FESTIVALS}

It seems that folk wrestling matches were held at nearly every major festival, aiming to attract crowds, gain fame, and communicate with people outside the strict boundaries of the village. On the basis of literary sources, the article 
describes some of these festivals that were performed in East Rumelia (presentday Bulgaria), East Thrace (present-day Turkey) and Evros. In the cases described below, organizing the matches were the responsibility of the church committee and local notables of the village where the festival was held.

Kavakli. Before 1923, wrestling matches were held in Kavakli town, East Rumelia, by the Greeks as part of a three-day festival of the Holy Trinity. On the third day of the festival the organizers of the match set up a wrestling arena on an outdoor threshing square. The wrestlers smeared their body with oil and participated in a wrestling match. People gathered around the arena and with great enthusiasm encouraged and cheered (in Bulgarian or Greek) their favorite wrestler on. The wrestlers wore periskelida (kispeti) which stretched from below the chest to above the knee. The winner was usually awarded a special ram or two sheep (Kolozov-Markidou 1981: 208-209).

Samacovi. Wrestling matches were also organized in the town of Samacovi (present-day Samokov in Bulgaria) during the festival of St John the Baptist, also named John Stafila. The matches were performed in the courtyard of the church of Prophet Elijah, which was situated just outside the town in the fields (Kiakidis 1942: 196).

Stenimachos. In the town of Stenimachos (present-day Asenovgrad in Bulgaria) the local population honored St Tryphon, the patron saint of vineyards and fields. People slaughtered a calf (the sacrificial ritual was called kourbani) in order to please the saint, and the sacrificial animal was divided among the surrounding villages. After the ceremony, wrestling matches took place on the village square and the winner was awarded a lamb (Megas 1992: 93).

Karaagach. Just a few kilometers from Adrianople (Edirne) the town of Karaagach was built on the bank of the Arda River. On the name day of St Theodore wrestling matches were held in this town. A committee mainly consisting of members of the Karaagach church committee organized wrestling matches and went around the stores of the village to collect prizes for the wrestlers (Tolidis 1985-87: 213).

Kastanies. In Kastanies in East Thrace, wrestling matches were organized until 1923. On the feast of St George, after the end of the Holy Mass, wrestling events were organized for the local population, Klaliotes, but also for Turkish wrestlers (Saranti 1937: 417-419).

Heraklia. The winner of the wrestling match held on the feast day of St George in Heraklia, East Thrace, was awarded a sheep. This being a special occasion, the sheep was ritually decorated while singing to it. Wrestlers, wearing leather 
periskelida, oiled themselves and competed with each other. The wrestling was accompanied by the playing of tambourines and pipes. According to the local rules, the match was won by the contestant who managed to throw his opponent so that his back touched the ground three times; this was the case also in the ancient times. The winner was awarded a ram (in a ritual of kourbani) and the best neckerchief (tsevre). The winner, traditionally naked, tied the neckerchief around his neck and walked around the crowd to receive prizes. The holder of the second and the third place were also awarded neckerchiefs as prizes. In these wrestling matches Turks were allowed to participate (Kourilas 1957: 122-123).

Didymoteicho. The wrestling matches which were held at Pentecost in Didymoteicho, where famous wrestlers from all over Thrace and Macedonia gathered to, had valuable prizes. According to Manakas (1963: 50), also Bulgarian and Turkish wrestlers participated in the event before the Second World War. For example, a highly famous wrestling match was held on the Feast of Pentecost between Soulios, a protégé wrestler of the Turkish commander of Adrianople, and Dimotianou Arhodis. Any prominent nobleman took pride in supporting a high-level wrestler, whose victories, in turn, enhanced the nobleman's prestige. The match between Soulios and Arhodis attracted many spectators; the balanced fight lasted for a long time and resulted in the death of Soulios. The result was virtually an insult to the Turkish Commander (Manakas 1963: 50-51).

Each year, a similar wrestling match was organized in the course of a major trade festival at the end of September. This festival became widely known as Sersem Festival ('the festival of indecency') after a wrestler's periskelida was torn down by his opponent during a wrestling match, resulting in an indecent exposure of the unfortunate wrestler (Kondos 2001: 9).

Asvestades. Without doubt, many festivals were held on the feast days of St Constatine I and St Helen(a) in the area of North Evros. The festival held in Asvestades is remarkable because of a legend connected to it. After the end of the Holy Mass, a wrestling match was held which inspired a song sung even today. Young men and women still dance the famous Thracian dance Zonaradiko and sing about the tragic end of Thanasis, the wrestler who disregarded his mother's advice. According to the legend, Thanasis's mother had a premonition and she tried to talk his son out of participating in the wrestling match. Thanasis ignored her advice. He defeated nine opponents but the last one, Doulis, tricked him and threw him on the ground so violently that Thanasis died in the fall (Kondos 2002: 3). 
Sapes. In Sapes, the Rhodope prefecture, wrestling matches were organized during a great trade festival in September until 1939. Christians and Muslims (Turkish-born and Pomaks, Bulgarian-speaking Muslims from the village of Kehros), but also Turkish wrestlers from Turkey took part in these matches. These games were very famous and gathered many spectators even from the neighboring areas. The prize for the winner was usually a zigouri, a two-yearold lamb, sometimes also a calf (Tsitsonis 1981: 255-339).

Xylagani. The people of the village Xylagani in the Rhodope prefecture must have adopted the customs of wrestling followed in East Rumelia, more specifically, in Megalo Vogialiki (in present-day Bulgaria), the area from where they had come. Until the 1960s, wrestling was performed during the festival in Xylagani, and the winner was awarded a lamb (Mountzakis 1985-1987: 274276).

\section{Wrestling matches at traditional (folk) events in Evros prefecture}

Folk matches of wrestling were held at different celebrations and festivals in Evros. In the village Rizia and the Ilia prefecture where they celebrated the ritual procession (aiming to satirize the Turkish oppression and lead by bey), wrestling games usually accompanied the celebrations. Wrestling was also organized in the Ftelia village on the festival on St Thomas's Day, in Komara on the feast of St Kyriaki, in Sitochori on August 16, in Dikaia on the feast day of St Tryphon, in Ormenio and in Kastanies on St George's Day.

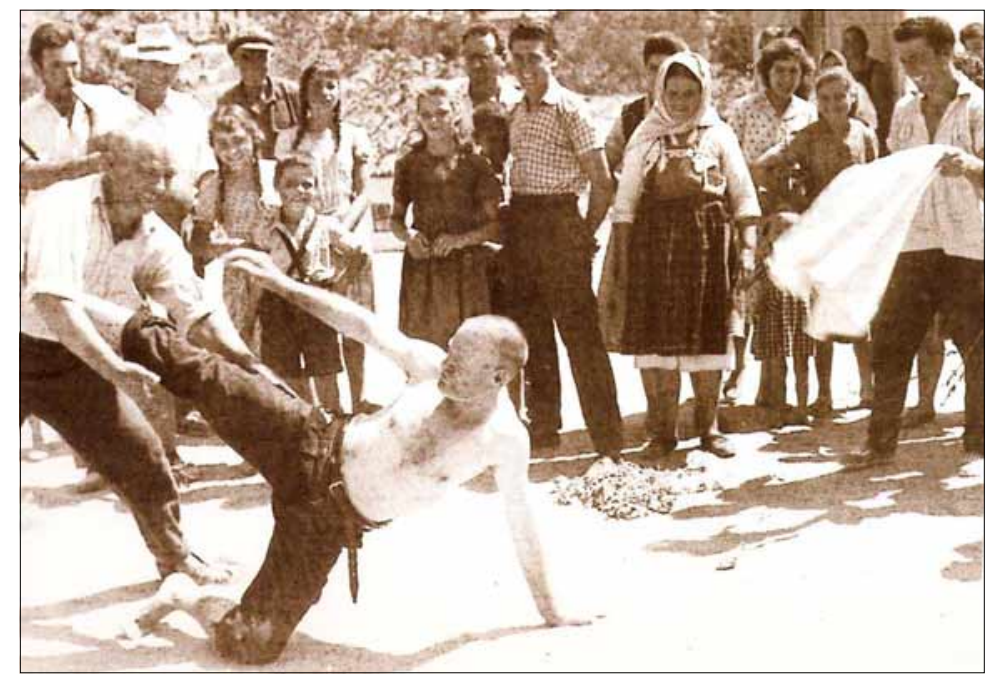

Figure 4. Wrestling event at a wedding in Karoti of Didymoteicho region to the accompaniment of bagpipes in 1960. 
The local people in Kastanies, northern Evros prefecture, raised money in the stores on the eve of the festival for the prizes (a neckerchief, a piece of cloth, a shirt) to each participating wrestler. After the festive holy mass, the wrestling matches took place in an open area on the river bank to the accompaniment of a tambourine and two pipes.

St George was worshipped throughout Thrace with great pomp and ceremony. The celebration on this day had regional variations but entailed sacrifices of animals (kourbani), agape feasts, but also wrestling games in which the wrestlers made a promise to St George: "St Georgios, help me to win and I will make you an omelet" (Kourilas 1957: 117).

\section{Wedding wrestling matches}

Wrestling was very often performed during weddings. Usually the groom's relatives organized wrestling matches towards the end of the wedding ceremony to entertain the invited guests. At the village square or on the outdoor threshing floor the wrestling match was prepared and the invited and uninvited wrestlers from the groom's village or the surrounding area participated. There were no rules as to how the wrestlers were arranged in pairs since the spectators served as the judges and the wrestling committee. After the end of the fight the wrestlers walked among the spectators and took from each one a small voluntary donation which the winners and the defeated wrestlers shared. The family who organized a wrestling match had big colorful neckerchiefs, which they offered to the wrestlers and members of the band which played at the match. Sometimes the prize for the winner was a lamb, which the wrestlers, both the winners and the defeated, ate at the banquet and by that became friends again. Analogous matches were performed in the villages of North Evros (Ormenio, Karoti) and in East Thrace (Kessani, Raidestos) (Tolidis 19851987: 21-217).

\section{FOOTRACES}

Footraces were not very popular among Thracians. It seems that wrestling matches and horse races outshone footraces with their glamour and undermined any other athletic activity. Reliable evidence about the existence of footraces comes from Maistro in Alexandroupoli. On the name day of St Marina (St Margaret) on 17 July, the festival attracted people from Alexandroupoli and the surrounding area. Before 1920, footraces among the youngsters of the villages Apalos and Maistro were organized by the communal council, who 
along with the priest and the local teacher constituted the jury. These 1.5 kilometers long footraces were for teenage and adult male athletes. The starter followed the runners on horseback. The race winner was the first to cross the finish line and touch the flag of the foreman of the jury. A sheep was given as a prize to the runner who finished first and neckerchiefs to the winners of the second and the third place. To raise money for the prizes, a plate was passed among the congregation during the morning mass. The winner was declared "an upstanding man of Maistro" (Mamelis 1934: 174-175).

According to the sources mentioned above, a footrace was also performed on the name day of St Kyriaki in the Komara village by young school children. Still, footraces were always secondary compared to wrestling and horse racing.

\section{CONCLUSION}

Athletic events were held at almost every festival and celebration in Thrace. Gradually, games and matches not only became the natural course of an event or celebration, but many a time they functioned as a ritual part of a celebration, indispensable for ensuring a good year, fertility of the land and flocks. Furthermore, athletic events were also important in adding popularity and prestige to the celebrations, promoting the festival in the neighboring villages and educating the youth who assisted and watched the games. Churchyards, outdoor threshing floors, hillsides, and other open areas formed the arenas where the games were performed. Church wardens served as official judges of the games and awarded the prizes along with the priest. Winners of these athletic events were mostly awarded lambs and goats - these were offers by church congregations or offerings by local shepherds who wished for a good year for their flock.

Horse races were widely known in Thrace. On large grasslands, the plains and riverside areas, Thracians used to breed horses. Horses were not only used as a means of transport, or for helping people with their needs, but they played an indispensable role in the life of people, functioning as symbols of their owner's status and prestige in the community. Thracians believed that a person could be strong enough to run, to wrestle, to win, but it was a completely different thing to be a horse rider on a beautiful horse, to become one with it and run fearless, being associated with the heroes of fairy tales or St George. Horse races were also organized at some festivals and special weddings. 
The most popular kind of sports games in Thrace was wrestling, perhaps owing to its popularity also among Muslims, Pomaks and Bulgarians. Even today, at the festival of "Giagla" (an area on the top of Mt. Rhodope) which takes place in the mountainous area of Hilgia on August 3, the Pomaks organize major wrestling matches which bring together wrestlers from the entire Balkan area (Varvounis 1996; Zeginis 1988: 238-239; 1991: 77-94).

Thrace and especially the area of South Evros organized wrestling matches not only at various festivals, but also in the context of other traditional celebrations like the ritual procession of bey and at special weddings. Great wrestlers were known in the same area and, more specifically, in Ampelakia, Asvestades, and Palli.

From the above it concludes that the people of Thrace, who were inspired by nature and guided by their ethnic culture, organized and participated in folk sports games which were held without following the strict formal structure of today's athletic events. These spontaneous sports events, as it was the case in ancient times, were associated with religion, because they were often held at religious festivals. Owing to these folk games, the Greek athletic events have survived up today as an expression of the everyday activities of the youth and as a representation of their physical and psychological uprightness.

\section{REFERENCES}

Basogianni, Despoina 1993. Gymnastiki laografia. [Folkloric Gymnastics - Folk Games of Western Thrace.] Elliniki Agogi, Vol. 1, pp. 7-10.

Ekaterinidis, Georgios 2000. Folk Culture. Thrace. Komotini: Region of East Macedonia and Thrace, pp. 286-335.

Kiakidis, Theodoros 1942. Diafora laografika Samakoviou. [Different folklore from Samacovi.] Thrakika Vol. 17, pp. 196-197.

Kolozov-Markidou, Maria 1981. Ethima kai viomata apo to Kavakli. Thrakiki Epetirida. [Customs and experiences from Kavakli. Thracian Archives.] Vol. 2, pp. 208-209.

Kondos, Paschalis 2001. Megali zoemporiki panigiri sto Didimotiho tis paradosis. [Great animal trade festival in Didymoteicho.] Newspaper Eparhiakos Typos, 22 Sept 2001, p. 9.

Kondos, Paschalis 2002. Gemato mnimes tis paradosis to panigiri tou ai- Konstantinou.[The full of memories festival of St Konstantinos in Asvestades.] Newspaper Eparhiakos Typos, 20 May 2002, p. 3.

Kourilas, Eleni 1957. O kavalaris Agios Georgios. Arhion Thrakikou Glossikou kai Laografikou Thesaurou [The horse rider St George. Records of Thracian Folklore \& Linguistic Treasures.] Vol. 22, pp. 17-136.

Ktenidis, Dimitrios \& Kotinis, Georgios 1969. Laografika Thouriou Didimotihou. [Folklore of Thourio Didymoteicho.] Thrakika. Vol. 43, pp. 136-137.

Mamelis, Katerina 1934. Oi athlitikoi agones tou horiou Maistrou. [The athletic games of the village Maistros of Evros.] Elliniki Agogi. Vol. 2, pp. 174-175. 
Manakas, Dimitrios 1963. Istoria Didimotihou. [History of Didymoteicho.] Thrakika Vol. 37, pp. 12-93.

Mavromatis, Theodoros 1939. Oi ippikoi agones tis palias Anchialou. Arhion Thrakikou Glossikou kai Laografikou Thesaurou. [Horse racing in old Anchialos: Coins and inscriptions. Records of Thracian Folklore \& Linguistic Treasures.] Vol. 23, pp. 61-63.

Megas, Georgios A. 1992. Ellinikes giortes kai ethima tis laikis latreias. [Greek Feasts and Customs of Popular Cult.] Athens: Estia.

Mountzakis, Niki 1985-1987. I giorti tis analipsis stin Xilagani. [Celebration of Christ's Ascension in Xylagani of Komotoni.] Thrakika. Vol. 5, pp. 274-276.

Nimas, Theodoros 2002. Athlitikes drastiriotites sto elliniko dimotiko tragoudi. [Athletic activities in Greek folk song.] Trikalina. Vol. 22, pp. 135-188.

Nimas, Theodoros 2000. The Athletic Games as a Criterion for the Choice of a Husband in Greece. Myth and Reality. Nikephoros Vol. 13, No. 6, pp. 221-240.

Nimas, Theodoros 1997. Oi gamilies hippodromies stin periohi Trikalon. [Wedding horse racing in the area of Trikala.] Trikalina. Vol. 17, pp. 375-397.

Oberhumer, E. 1936. Thrake (Grenzen). Realencyclopädie VIA 1 cols. 394-396.

Samsaris, Dimitrios 1980. O exellinismos tis Thrakis kata tin elliniki kai romaiki arhaiotita. [The Hellenization of Thrace during the Greek and Roman Antiquity.] Thessaloniki: Aristotle University of Thessaloniki.

Saranti, Maria 1937. Apo ta panigiria tis Thrakis. [From the festivals of Thrace.] Thrakika. Vol. 8, pp. 417-419.

Svolopoulos, Konstantinos 2000. Western Thrace in the body of the Greek state. Thrace. Komotini: Region of Eastern Macedonia and Thrace, pp. 265-283.

Tolidis, Georgios 1985-1987. Anamnisis apo tin Anatoliki Thraki - Athlitikoi palaistikoi agones. [Memories from East Thrace: Athletic Wrestling matches.] Thrakika. Vol. 5, pp. 210-217.

Tsiantas, Konstantinos 1980. Ta agonismata ton kleftarmatolon. [The Athletic Activities of Armatolos.] Ioannina: University of Ioannina.

Tsitsonis, Christos 1981. Sapes. Thrakiki epetirida. [Thracian Archive.] Vol. 2, pp. $255-339$.

Varvounis, Manolis G. 2001. Christian and Islamic parallel cultural traditions in the popular culture of the Balkan people. In: M.G. Varvounis (ed.) Studies on Greek Folk Culture. Komotini: Municipality of Komotini, pp. 195-216.

Varvounis, Manolis G. \& Dimaki, Maria 2000. To panigiri tou Agiou Athanasiou sti Nigrita. I Nigrita tes Visaltias dia mesou tes istorias. [St Thomas's Festival in Nigrita. Nigrita of Visaltia through history.] Thessaloniki: Municipality of Nigrita, pp. 83-119.

Varvounis, Manolis G. 2000. Kina stihia ston paradosiako politismo ton valkanikon laon. [Common elements in traditional culture of Balkans.] In: V. Manolis (ed.) Meletimata ellinikis laografias. [Short essays in Greek folklore.] Xanthi, pp. 233-248.

Varvounis, Manolis G.1996. Laografika ton Pomakon. [Folklore of Thracian Pomaks.] Athens.

Zeginis, Evangelos 1988. O bektasismos sti Ditiki Thraki. [Bektasism in West Thrace.] Thessaloniki: Institute for Balkan Studies.

Zeginis, Christos 1991. Eortologio kai agiolatreia ton bektasidon tes Ditikis Thrakes [Church calendar and saints' worship of Bektasides of West Thrace.] Proceedings of the 6th Folklore Symposium of North Greek Area. Thessaloniki: Institute for Balkan Studies, pp. 77-94. 